\title{
Bridging Iranian Exporters with Foreign Markets : Does Diaspora Matter?
}

Jamal Ibrahim Haidar

Paris School of Economics, Paris, France

Seyed Hossein Mirjalili

Institute for Humanities and Cultural Studies, Tehran, Iran

\begin{abstract}
After matching a rich micro-level Iranian customs dataset with a macro-level crosscountry database on Iranian diaspora stocks, we establish that diaspora matters for dynamics of Iranian exporters. We document the extent to which Iranian emigrants foster exports through both intensive and extensive margins at the micro-level. We show that destinations with more emigrants from Iran attract more Iranian exporters and allow them to survive longer and grow faster. One plausible explanation is that the diaspora channel reduces the fixed cost of exporting that Iranian exporters incur to enter a destination, those related to creating distribution channels, and those associated with learning about market demand. Our results add firm-level insight to the burgeoning literature on the channels through which emigration could impact economic integration. As Iran is now trying to integrate more with the global economy, these results suggest

* Corresponding Author: Jamal Ibrahim Haidar; Paris School of Economics, University of Paris 1 Pantheon Sorbonne, France; Tel: +336 95606268, E-mail: jihaidar@psemail.eu.

Co-author: Seyed Hossein Mirjalili; Institute for Humanities and Cultural Studies, Tehran, Iran; E-mail: h.jalili@ihcs.ac.ir.

Acknowledgements: This paper was first submitted in April 2014 and accepted for publication in April 2016. The authors would like to thank 2 anonymous referees for helpful comments as well as the Iranian Customs Administration for granting access to the data. Maryam Zaid Bassam provided inspiration. The usual disclaimers apply.
\end{abstract}


that Iranian embassies across the world have a role to play in bridging the gap between Iranian diaspora and exporters through trade promotion exhibitions and workshops to encourage greater trade between Iran and the rest of the world.

JEL Classifications: F10, F20, F22, F23, L14, L25

Keywords: Economic Integration, Diaspora, Exporters Dynamics, Trade

\section{Introduction}

Countries do not do trade: it is people and firms that export and import. This basic truth makes it obvious that understanding exporter-level facts is essential to formulating a trade policy. There is evidence that most exporters export to a limited set of destinations and that the fixed costs of exporting matter for market penetration. ${ }^{1}$ However, the available literature does not fully explain the nature of and variation in the fixed costs of exporting. For example, we still do not know the precise reasons for exporters entering certain markets but not others or how different components of destination entry costs affect exporters dynamics and performance at the destination level. In this study, we examine the relation between emigration and exporters dynamics - by creating network and demand channels, emigrants can reduce entry costs for exporters from their home country to their new destination.

Much has been written about the linkage between trade and migration. One key question in this literature is why there should be such link. Among the potential answers generally discussed are demand links (emigrants want goods from the home country); information links (emigrants know what goods are produced in their home country and what demands in the host country may be satisfied by those goods); and asymmetric information/contracting links (emigrants may constitute a bridge to countries with poor contractual environments, substituting personal connections as bonding for poor contract enforcement). ${ }^{2}$

In this study, we investigate the emigration-trade linkage at the micro level. Precisely, we study the extent to which Iranian diaspora affects micro-level dyadic export relations

\footnotetext{
See Helpman et al. (2008), Chaney (2008), and Eaton et al. (2011).

${ }^{2}$ See Coughlin and Wall (2011).
} 
between Iran and destination countries. After merging exporter-level Iranian customs dataset with data on Iranian emigration stocks across destinations, we add evidence to the existing body of knowledge on whether emigrants enhance entry and exports of exporters to certain markets more than others. In other words, we look at whether diaspora is a channel that exporters use to reduce cost of entry to new markets and create demand for their products in these destinations.

We focus our study on Iran for three reasons. First, the occurrence of emigration from Iran around the revolution of 1979 along with the relatively low change of emigration from Iran between 1995 and 2006 (i) rest the concern that emigration may be endogenous to exporters dynamics and (ii) allow studying whether emigration affects exporters dynamics by contributing to destination-specific heterogeneity in entry costs. Second, two phases of emigration movements have been a feature of $20^{\text {th }}$ century Iran. The 1950 1979 phase was triggered by Iran's slow economic recovery. The second phase of Iranian emigration occurred after Iran's 1979 revolution. This wave of emigrants included large numbers of professionals, entrepreneurs, and academics. Thus, there is heterogeneity and no selection bias across emigrants from Iran. Third, Iran had a unique experience as it was under sanctions during our study period, which spans the duration of our dataset. In spite of the different (diplomatic, trade, financial, and banking) restrictions it faced, Iranian export volumes are still significant (Haidar, forthcoming). However, the role of Iranian diaspora in export dynamics has not been explored yet, which is why it is the subject of this study.

Our results show that the level of Iranian emigrant stocks in a given destination is important in explaining why exporters from Iran enter and grow more and faster in certain markets than in other markets. These results suggest that emigrants play a role in creating demand at the destination level as well as in reducing market entry cost. After controlling for exporter heterogeneity and the gravity model variables, our analysis shows that Iranian exporters tend to enter more frequently destinations having a higher number of Iranian emigrants. In addition, we demonstrate that conditional on exporter entry at the destination level, Iranian emigrants are a key determinant of Iranian exporter-level sales at the destination level. As Iran is now trying to integrate more with the global economy, these results imply that Iranian embassies across the world have a role to play in bridging the gap between the diaspora and Iran by promotion greater trade between Iran and the rest of the world. In addition, these results highlight the importance of emigration for trade and economic growth for countries with different economic and cultural backgrounds. 
The remainder of the study is outlined as follows. Section II reviews the relevant literature and positions our work within it. Section III exhibits a theoretical framework showing how emigration can affect exporters dynamics by reducing the fixed cost of exporting. Section IV introduces the data used in this study. Section V describes the empirical methodology and provides econometric evidence on the impact of emigration on exporters dynamics at the destination and exporter levels and also presents robustness checks to confirm our results. Section VI concludes the study.

\section{Literature Review}

One strand of literature studies the relation between cultural ties and trade behavior. A rationale for the positive effects of cultural ties on aggregate trade lies in the fact that language, trust, and familiarity are among the factors facilitating building relations between exporters and importers in different countries. ${ }^{3}$ If immigrants to a given destination help exporters from their home country to enter their current destination, then it is likely that bilateral trade will relatively increase. Immigrants' ties to their home countries can play a key role in fostering bilateral trade linkages. Immigrant ties include knowledge of home-country markets, language, preferences, and business contacts that have the potential to decrease trade transaction costs.

On related fronts, Barro and McCleary (2003) and Giuliano (2007) examined the effect of culture on economic outcomes. Anderson and Mercouiller (2002), Berkowitz et al. (2006), and Nunn (2007) examined the effect of country-level institutional variables on trade while Melitz (2008) showed that the significance of a common language in foreign trade hinges on translation as well as the ability to communicate directly. Moreover, Rauch and Trindade (2002) established that ethnic networks increase bilateral trade, suggesting that business and social networks have a considerable quantitative impact on international trade by helping match buyers and sellers.

The role of familiarity in trade has a long tradition as well. As shown by Anderson and van Wincoop (2004) and Huang (2007), gravity estimations typically confirm that familiarity augments trade. Trefler (1995) advanced familiarity as a potential explanation

${ }^{3}$ DeBruine (2002) showed that people trust ones who look like them more than those who do not. 
for the mystery of the missing trade. He maintained that there must be extra transactions costs on top of transport costs since actual trade barriers and transport costs are too low to account for the difference between the size of observed trade flows and the predictions from standard models. The estimated effects of distance in gravity models are typically too large, given the size of actual transport costs (Hummels and Schaur 2013).

Related aggregate-level evidence is available for many economies. For example, Blanes and Martin (2006) demonstrated that the stock of immigrants in a country positively affects the share of its bilateral intra-industry trade. Using country-level trade data from Spain, they found that immigration contributes to reduction in trade transaction costs and this would benefit more intra- than inter-industry trade. In addition, Combes et al. (2005) investigated the role of social networks in shaping trade among French regions. Compared with a situation without networks, migrants are shown to double bilateral trade flows while networks of firms multiply trade flows by as much as four times in some specifications.

Moreover, Girma and Yu (2002) studied the link between immigration and trade using the United Kingdom (UK) data. They found that immigration from non-Commonwealth countries has a significant export-enhancing effect, whereas immigration from Commonwealth countries has no substantial effect on exports. They conjectured that this result could be because immigrants from the UK's former colonies do not bring with them any new information that can help substantially reduce the transaction cost of trade between their home countries and the host nation. Their study also revealed a pro-imports effect of immigration from the non-Commonwealth countries, whereas immigration from the Common wealth appears to be reducing imports, perhaps reflecting trade-substituting activities by immigrants.

In addition, Murat and Pistoresi (2009) studied the relationship between emigration, immigration, and trade using Italian data. They found that networks of Italian emigrants in foreign countries boost bilateral trade. Piperakis et al. (2003) also investigated the influence of immigration into Greece on the volumes of Greece's bilateral trade using a gravity modeling approach. Their results show that immigration positively affected the volume of Greece's bilateral exports. This is consistent with immigration-reducing transactions or trading costs on Greece's exports.

For Canada, Head and Ries (1998) highlighted that immigrants may expand trade with their country of origin owing to superior knowledge of or preferential access to market opportunities. The authors tested this proposition using Canadian trade data with 136 partners from 1980 to 1992 . In an augmented gravity equation, they found that a 
$10 \%$ increase in number of immigrants is associated with a $1 \%$ increase in Canadian exports to the immigrant's home country and a 3\% increase in imports.

For the United States (US), Gould (1994) showed empirical results that immigrant links have historically been important in increasing bilateral trade flows with immigrants' home countries. Ching et al. (2004) also investigated the trade-related importance of Chinese and other immigrants into the US. Using state-level export data for 28 immigrant source countries in 1993, the authors found a strong immigrationtrade link. Using data from the World and European Values Surveys, White and Tadesse (2008) calculated cultural distances between the US and 54 immigrant home countries and examined the influences of cultural distance and immigrant populations on US imports from and exports to immigrants' home countries during the 1997 2004 period. They indicated that for both US imports and exports, the trade-enhancing effect of immigrants partially offsets the trade-inhibiting effect of cultural distance. Further, when they decomposed their measure of cultural distance into two component dimensions and revisited the immigrant-trade relationship, they found significant variation in the extent to which immigrants counter the trade-inhibiting influences of the underlying dimensions of culture for both US imports and exports. Their findings imply that immigrants exert pro-development effects by countering the trade-inhibiting influences of cultural differences between their home and host countries. ${ }^{4}$

In the same spirit, Law et al. (2013) examined the hypotheses that a greater stock of migrants in New Zealand from a particular country leads to more trade between that country and New Zealand, and a greater stock of New Zealanders living overseas in a particular country leads to more trade between that country and New Zealand. They applied panel data techniques, within the framework of a standard gravity model of trade, to a dataset consisting of information on 233 countries in each of the 26 years between 1981 and 2006. Their results indicate that migration does indeed stimulate trade.

The mechanism by which familiarity enhances exports has, however, to a large extent remained unresolved, although the effect of familiarity on trade has been welldocumented. We add to the existing body of knowledge by matching micro-level data on exporters to macro-level data on emigration to establish whether emigrants from Iran enhance entry and exports of Iranian exporters to certain markets more than others. In

\footnotetext{
${ }^{4}$ Bandyopadhyay et al. (2008) also provided estimates of the effects of ethnic networks on US exports. Borjas (1995) suggested that the economic benefits from immigration to US could be increased considerably if the US pursued an immigration policy that attracted a more skilled immigrant flow. In addition, see Boisso and Ferrantino (1997), Kohli (2002), and Bardhan and Guhathakurta (2004) for related work on immigration and trade.
} 
other words, we look at whether diaspora is a channel that Iranian exporters use to reduce cost of entry to new markets and create demand for their products in these destinations.

\section{Theoretical Framework}

The exports of a country to a given destination depend on the number of exporters (extensive margin) and exports per exporter (intensive margin). Adjustments on each respective margin determine the variations in exports. Chaney (2008) and Helpman et al. (2008) made progress in explaining why and how trade flows adjust on each of the margins. In these models, the rationale for an extensive margin that varies across markets stems from a combination of destination-specific fixed entry costs and exporter heterogeneity in terms of productivity. While both the extensive and intensive margins vary with variable export costs and market size, fixed entry costs only affect the extensive margin. Following Chaney (2008), the world is composed of multiple different destinations. At each destination $d$, we define consumer preferences for a differentiated variety by a Dixit-Stiglitz Constant Elasticity of Substitution (CES) utility function. Each exporter produces a horizontally differentiated variety $e$ by means of a Ricardian technology, with unit cost $\frac{w}{\varphi(e)}$. Exporter $e$ maximizes a destination-specific profit function given by

$$
\pi_{d}(e)=\left(p_{d}(e)-\frac{w}{\varphi(e)} \tau_{d}\right) q_{d}(e)-F_{d}
$$

where $p_{d}(e)$ is the export price; $q_{d}(e)$ is the quantity of variety $e$ demanded at destination $d ; w$ is the wage level common to all exporters; $\phi(e)$ is an exporter-specific productivity parameter randomly drawn from a distribution with cumulative density function $G(\phi) ; F_{d}$ is a fixed cost of exporting incurred by exporter to enter to destination $d$; and $\tau_{d}$ is an iceberg transportation cost.

If exporter $e$ exports to destination $d$, then the net contribution of this destination to profits is

$$
\pi_{d}(e)=\frac{x_{d}(e)}{\sigma}-F_{d}
$$


where $\sigma>1$ is a constant elasticity of substitution between any two goods and $x_{d}(e)$ denotes export revenues. Heterogeneity in firm efficiency and firm-destination demand shocks imply that not all exporters will find it profitable to export to country $d$. The probability of exporting is given by:

$$
\mathrm{P}\left[E_{d}(e)=1\right]=\mathrm{P}\left\{\begin{array}{l}
{\left[(\sigma-1) \ln \left(\frac{\varphi(e)}{w}\right)+(\sigma-1) \ln a_{d}(e)\right.} \\
\left.+\ln X_{d}-(\sigma-1) \ln \tau_{d}+(\sigma-1) \ln P_{d}-\ln \sigma F_{d}>0\right]
\end{array}\right.
$$

where $P_{d}$ is the price index in country $d$ and $a_{d}(e)$ are exporter-destination demand shocks as shown by Eaton et al. (2011). We assume that $a_{d}(e)$ represent exporter $e$ 's connections with consumers in destination $d$. One way to interpret it is that by incurring $F_{d}$ a firm with more contacts in country $d$ (i.e., a firm with a larger $a_{d}(e)$ ) is able to reach a larger number of buyers at destination $d$. Using Equation (3), we can write the freighton-board export revenue in destination $d$ as:

$$
\ln x_{d}^{f o b}(e) \equiv \ln \frac{x_{d}(e)}{\tau_{d}}=\left\{\begin{array}{l}
{\left[(\sigma-1) \ln \left(\frac{\varphi(e)}{w}\right)+(\sigma-1) \ln a_{d}(e)\right.} \\
\left.+\ln X_{d}-\sigma \ln \tau_{d}+(\sigma-1) \ln P_{d}\right]
\end{array}\right.
$$

We are interested in the effect of immigrants on exporters dynamics. Equation (3) shows that by lower $F_{d}$, immigrants are expected to increase the likelihood of export participation, i.e., by facilitating trade relationships or by enhancing the ease of obtaining required documentation to start trading. It also describes that for a given level of productivity and fixed entry costs, firms with stronger networks in a given destination (i.e., firms with larger $a_{d}(e)$ ) are more likely to sell there. Equation (4) shows that export intensity is independent of $F_{d}$ but may still rise with immigrant networks due to idiosyncratic firm-destination demand shocks $a_{d}(e)$.

\section{Data}

We employ a rich non-oil exporter-level disaggregated dataset provided by Iranian 
Customs. To check the data quality, we compared Iranian Customs data with UNComtrade data and mirror data (what other countries report as imports from Iran). The customs dataset matches both UN-Comtrade data and mirror data. ${ }^{5}$ However, compared with UN-Comtrade data, this dataset includes customs exporter records for the period January 2006 to June 2011, allowing monitoring dynamics at the micro level (i.e., entry and exit rates, export volumes, products, distributions, and prices and growth at the exporter-product-destination level). This dataset allows distinguishing between the number of products that are exported by each exporter to each destination (the extensive margin) and the export value per product per exporter to each destination (the intensive margin). It is worth noting that the use of exporter-level data enables the construction of export margins with an exporter-product-destination dimension, which is not the case with product-level databases (e.g., UN-Comtrade). All Iranian non-oil exporters and export transactions are included in the sample. The dataset includes the following variables for each export transaction: exporter ID, product ID, ${ }^{6}$ destination of shipment, value of exports, and year of transaction. Iranian Customs also ask exporters to report weights (in addition to value) of each exporter's product shipment. The sample includes 479,719 annual customs transactions. The universe of exporters during this period consisted of 35,953 exporters, among which not all exported every year. Particularly important for this study is the fact that Iranian Customs collects data at the exporterproduct level. Information on 3,865 unique products is included in the dataset. The HS-6 digit level product classification illustrates the narrowness of product definitions and the richness of micro-level information available in the dataset. ${ }^{7}$

In addition, we exploited the Global Migrant Origin Database (GMOD) ${ }^{8}$ to obtain information regarding the number of Iranian immigrants to each country that imports from Iran. The most updated data is available for the year 2000 and for the 180 destinations mentioned in our exporter dataset. The full GMOD data set consists of a $226 \times 226$ matrix of origin-destination data. GMOD deduces the data from each country by disaggregating the information on its migrant stocks as reported in its year 2000

\footnotetext{
${ }^{5}$ The data quality check shows that Customs-reported aggregate exports represent $98.5 \%$ of UN-Comtrade data and overlap with mirror data at the destination level.

${ }^{6}$ Products are disaggregated at the HS-6 digit level.

7 A portion of transactions in the dataset includes HS- 8 digit-level product classification, but the majority of transactions use HS- 6 digit-level product classification. To ensure consistency in the analysis, we aggregate and use the data at the HS-6 digit level. For each relevant table in the empirical section, we repeat the analysis using data available at the HS- 8 digit level product classification, and the results hold. To save space, throughout this study, we show the results at the HS-6 digit level product classification.

${ }^{8}$ The GMOD comes from the University of Sussex's Development Research Centre on Migration, Globalization and Poverty.
} 
population census. In addition, using the CEPII dataset on distance and the World Bank World Development Indicators, we supplemented the merged dataset with information on each importing country, namely, real Gross Domestic Product (GDP) (measured as PPP), GDP per worker, and the distance between its most populated city and Tehran (measured in $\mathrm{km}$ ).

Table 1 shows the distribution of Iranian exporters and exports across destinations. On average, each exporter exported to 2.5 destinations. However, this average value hides rich information. While the bulk $(76 \%)$ of exporters exported to one or two destinations, these exporters are small and account for only $16.6 \%$ of total Iranian exports. The exporters that exported to at least 10 destinations account for only $4 \%$ of all exporters but for more than half (56.9\%) of Iranian exports

Table 1. Distribution of Iranian exporters and exports

\begin{tabular}{|c|c|c|}
\hline Destinations per exporter & \% of exporters & \% of exports \\
\hline 1 & 62.5 & 9.9 \\
\hline 2 & 13.6 & 6.7 \\
\hline 3 & 7.0 & 5.2 \\
\hline 4 & 4.4 & 3.8 \\
\hline 5 & 2.8 & 4.0 \\
\hline $6-9$ & 5.6 & 56.5 \\
\hline$>10$ & 4 & 2.5 \\
\hline \multicolumn{2}{|c|}{ Average number of destinations per exporter } & \\
\hline
\end{tabular}

(Note) Calculations are based on customs dataset.

\section{Empirical Analysis}

In this section, we examine whether the number of Iranian immigrants at a given destination is important in explaining Iranian exporters dynamics. We test whether the 
stock of Iranian emigrants affects the number of exporters, products, entrants, exiters, and survivors at the destination level. In Table 2, we decompose Iranian aggregate exports into the extensive and intensive margins at the destination level. To do so, we decompose the Iranian exports into two different groups:

$$
\text { Exports }_{d}=\sum \text { exporters }_{d} \frac{\text { exports }_{d}}{\text { exporters }_{d}}=\sum \text { products }_{d} \frac{\text { exports }_{d}}{\text { products }_{d}}
$$

where exporters ${ }_{d}$ denotes the number of Iranian exporters exporting to destination $d$ and products ${ }_{d}$ denotes the number of Iranian exported products exporting to destination $d$. Then, we look at the relationship between these components and the number of emigrants from Iran to different destinations using a gravity equation:

$$
\ln _{\text {Exports }_{d}}=\alpha \ln \left(\text { Immigrants }_{d}\right)+\beta X_{d}+u_{d}
$$

where $X_{d}$ is a vector of standard gravity regressors, including the destination's economic size, distance between Tehran and the most populated city of the destination country, and whether destination $d$ is a landlocked country. The data show a clear result in Table 2. The number of Iranian immigrants to a given destination increases the numbers of Iranian exporters and products as well as the average export value per Iranian exporter and product. The results are statistically significant at the $1 \%$ level and the regression controls for destination size and distance from Iran as well as whether it is landlocked and shares a common language with Iran. While we use all the other variables as controls in our Ordinary Least Squares (OLS) regression, our primary focus is on the coefficients of immigrants. The estimates in column 2 of Table 2 show that Iranian exports to a given destination are significantly higher in the presence of larger number of immigrants.

We first disaggregate Iranian exports at the destination level (in column 3 and column 4 of Table 2) to the number of exporters and average export value per exporter and, second, to the number of products and average export value per product (column 5 and column 6 of Table 2). The estimates show that the increase in the number of exporters and products accounts for most of the positive and statistically significant effect of the number of Iranian immigrants at a given destination on total exports from Iran to that given destination, highlighting the role played by networks at the extensive margin. As the regression is an ordinary least squares, the regressions in columns 3-6 additively 
decompose the margins by which each of the extensive and intensive margins affects Iranian exports to a given destination.

Table 2. Impact of immigrants on exports at intensive and extensive margins

\begin{tabular}{|l|c|c|c|c|c|}
\hline $\begin{array}{c}\text { Dependent } \\
\text { variable }\end{array}$ & Exports & $\begin{array}{c}\text { Number } \\
\text { of exporters }\end{array}$ & $\begin{array}{c}\text { Average } \\
\text { export value } \\
\text { per exporter }\end{array}$ & $\begin{array}{c}\text { Number } \\
\text { of products }\end{array}$ & $\begin{array}{c}\text { Average } \\
\text { export value } \\
\text { per product }\end{array}$ \\
\hline $\begin{array}{l}\text { Number of } \\
\text { immigrants }\end{array}$ & $\begin{array}{c}0.113^{a} \\
(0.000)\end{array}$ & $\begin{array}{c}0.072^{a} \\
(0.004)\end{array}$ & $\begin{array}{c}0.041^{a} \\
(0.000)\end{array}$ & $\begin{array}{c}0.081^{a} \\
(0.007)\end{array}$ & $\begin{array}{c}0.032^{a} \\
(0.006)\end{array}$ \\
\hline $\begin{array}{l}\text { Gross domestic } \\
\text { product }\end{array}$ & $0.524^{a}$ & $0.321^{a}$ & $0.203^{a}$ & $0.402^{a}$ & $0.122^{a}$ \\
\hline Population & $(0.000)$ & $(0.000)$ & $(0.000)$ & $(0.004)$ & $(0.005)$ \\
\hline Distance & $0.219^{a}$ & $0.443^{a}$ & $0.125^{a}$ & $0.311^{a}$ & $0.201^{a}$ \\
\hline Common & $(0.000)$ & $(0.000)$ & $(0.000)$ & $(0.000)$ & $(0.000)$ \\
\hline language & $-1.375^{a}$ & $-0.742^{a}$ & $-0.633^{b}$ & $-0.837^{a}$ & $-0.538^{b}$ \\
\hline Landlocked & $(0.000)$ & $(0.001)$ & $(0.043)$ & $(0.009)$ & $(0.035)$ \\
\hline${ }^{a}$ & $4.893^{a}$ & $3.812^{a}$ & $1.081^{c}$ & $3.258^{a}$ & $1.635^{c}$ \\
\hline Destinations & $(0.000)$ & $(0.008)$ & $(0.089)$ & $(0.005)$ & $(0.070)$ \\
\hline R-squared & $-0.946^{a}$ & $-0.711^{a}$ & $-0.235^{a}$ & $-0.436^{a}$ & $-0.510^{b}$ \\
\hline
\end{tabular}

(Notes) (i) All variables, apart from language and landlocked, are in log terms. $p$-values are in brackets.

(ii) Statistical significance levels are denoted by ${ }^{a}(1 \%$ or less $),{ }^{b}(5 \%$ or less $)$, and ${ }^{c}(10 \%$ or less).

While the above results make a point, they do not allow us to study the importance of exporter heterogeneity, especially as immigrants are expected to reduce trade costs for exporters from their home country. The model in Section III above shows that the effect of immigrants on exporters dynamics depends on exporters characteristics. If we use the number of exporters and products as a measure of the extensive margin, then we will not be able to understand the importance of exporter heterogeneity when it comes to exporters dynamics. In addition, it is not optimal to use the average exports per exporter to measure the effects of immigrants on export intensity because a fall in variable cost of exporting may increase the exports of each exporter to a given destination as well as the entry of exporters (and thus lower average exporters per exporter) at a given destination. Thus, we now exploit the exporter-destination dimension of the data to understand the 
impact of immigrants on exporter entry and sales at the exporter-destination level.

First, we look at a more disaggregated level in the dataset, particularly at the exporter and product destination levels, to learn about the impact of immigration on exporters' entry and activities at the destination level. In Table 3, we highlight the impact of Iranian immigration networks on Iranian exporters and products entry to and survival rates as well as growth of export value per exporter at the destination level. The results show that an increase in the number of Iranian immigrants to a destination raises the Iranian exporters and products entry and survival rates at that destination as well as the growth of export value per exporter (columns $2-6$ of Table 3 ). These results suggest that immigration can reduce market entry costs for exporters given the connections that immigrants make at the destination.

Table 3. Impact of immigrant on entry, survival, and growth of exporters

\begin{tabular}{|c|c|c|c|c|c|}
\hline $\begin{array}{l}\text { Dependent } \\
\text { variable }\end{array}$ & $\begin{array}{l}\text { Exporter } \\
\text { entry rate }\end{array}$ & $\begin{array}{l}\text { Product } \\
\text { entry rate }\end{array}$ & $\begin{array}{c}\text { Exporter } \\
\text { survival rate }\end{array}$ & $\begin{array}{c}\text { Product } \\
\text { survival rate }\end{array}$ & $\begin{array}{l}\text { Growth of } \\
\text { export value } \\
\text { per exporter }\end{array}$ \\
\hline $\begin{array}{l}\text { Number } \\
\text { of immigrants }\end{array}$ & $\begin{array}{l}8.214^{a} \\
(0.000)\end{array}$ & $\begin{array}{c}6.452^{a} \\
(0.000)\end{array}$ & $\begin{array}{l}5.326^{a} \\
(0.000)\end{array}$ & $\begin{array}{l}7.093^{a} \\
(0.000)\end{array}$ & $\begin{array}{l}9.416^{a} \\
(0.000)\end{array}$ \\
\hline $\begin{array}{l}\text { Gross domestic } \\
\text { product }\end{array}$ & $\begin{array}{l}3.425^{a} \\
(0.000)\end{array}$ & $\begin{array}{l}2.691^{a} \\
(0.000)\end{array}$ & $\begin{array}{l}3.681^{a} \\
(0.000)\end{array}$ & $\begin{array}{l}5.214^{a} \\
(0.000)\end{array}$ & $\begin{array}{l}4.892^{a} \\
(0.009)\end{array}$ \\
\hline Population & $\begin{array}{l}2.113^{a} \\
(0.000)\end{array}$ & $\begin{array}{l}1.852^{a} \\
(0.000)\end{array}$ & $\begin{array}{l}2.734^{a} \\
(0.000)\end{array}$ & $\begin{array}{l}4.123^{a} \\
(0.000)\end{array}$ & $\begin{array}{l}3.781^{a} \\
(0.000)\end{array}$ \\
\hline Distance & $\begin{array}{c}-10.012^{a} \\
(0.001)\end{array}$ & $\begin{array}{l}-4.212^{a} \\
(0.005)\end{array}$ & $\begin{array}{l}-4.353^{b} \\
(0.033)\end{array}$ & $\begin{array}{l}-5.232^{a} \\
(0.007)\end{array}$ & $\begin{array}{l}-5.217^{b} \\
(0.021)\end{array}$ \\
\hline $\begin{array}{l}\text { Common } \\
\text { language }\end{array}$ & $\begin{array}{l}0.023^{c} \\
(0.051)\end{array}$ & $\begin{array}{c}0.047^{b} \\
(0.043)\end{array}$ & $\begin{array}{l}0.0311^{c} \\
(0.072)\end{array}$ & $\begin{array}{c}0.029^{c} \\
(0.091)\end{array}$ & $\begin{array}{l}0.042^{c} \\
(0.071)\end{array}$ \\
\hline Destinations & 180 & 180 & 180 & 180 & 180 \\
\hline$R$-squared & 0.62 & 0.67 & 0.63 & 0.68 & 0.53 \\
\hline
\end{tabular}

(Notes) (i) All independent variables are in log terms. $p$-values are in brackets.

(ii) Statistical significance levels are denoted by ${ }^{a}$ ( $1 \%$ or less), ${ }^{b}\left(5 \%\right.$ or less), and ${ }^{c}$ ( $10 \%$ or less).

As a robustness check, we also look at the effect of immigrants on exporters' entry using the following estimation: 


$$
P\left(\text { Entry }_{d}=1\right)=P\left(\alpha \ln \left(\text { Immigrants }_{d}\right)+\beta X_{d}+\gamma \ln \phi_{e}+u_{d}\right)
$$

where Entry $_{d}=1$ if exporter $e$ exports to country $d$ and $P$ is a probability distribution function. $\phi_{e}$ is a proxy for exporter productivity, proxied by exporter size. We use the log of exporter size (total sales) as a proxy of exporter productivity, given such measure can also reflect exporter heterogeneity. In heterogeneous firm models with multiple factors of production, exporter size tends to be positively correlated with measures of total factor productivity (Hsieh and Klenow 2009). $u_{d}$ is the destination error term. The destinationlevel regressors are the same as in Table 3.

Table 4 reports the results of the Linear Probability Model (LPM). It is important to note that linear probability models perform well when most of the covariates are discrete variables and take only a few values (Wooldridge 2003), which is the case here. The use of a linear probability model also allows us to include a set of dummies to control for many unobserved factors that, if omitted, could bias our estimates. One problem with linear probability models is that they can predict probabilities outside the $0-1$ interval. However, in our above estimations, the LPM will always predict probabilities bounded between 0 and 1 given we have dummy regressors in each estimation. In line with the model, the estimates in column 2 of Table 4 reveal that conditional on the attributes of the export destination, more productive firms are more likely to enter there. The coefficients associated with the customary gravity variables also present the expected sign: exporters are more likely to export to larger and geographically closer nations that are not landlocked. Of most interest to our analysis, the results in column 2 suggest that migrant networks have a positive and significant effect on the probability of exporting to a given destination. Doubling the number of Iranian emigrants in a potential destination increases the probability of export participation by about $2.1 \%$ point. This effect is not negligible.

For further robustness, in column 3, we use a linear probability model with exporter fixed effects. Rather than relying on a proxy to account for $\phi_{e}$, the LPM-FE estimator exploits solely the within-exporter variation in export entry across destinations, thereby accounting for both observed and unobserved exporter heterogeneity. As noted by Baldwin and Harrigan (2011), the LPM-FE estimator is more appropriate than the fixed effects probit and logit estimators, as the latter ones are inconsistent when the number of effects is large (incidental parameters problem, which is clearly the case here). In addition, they note that the LPM-FE is also preferable to random effects logit models as the latter embody the (unsuitable) assumption that exporter effects are orthogonal to 
country characteristics. Reassuringly, the LMP-FE estimator yields similar coefficients for the effects of emigrant stocks and common language on export entry.

Table 4. Robustness checks

\begin{tabular}{|c|c|c|}
\hline Dependent variable & $P\left(\right.$ Entry $\left._{d}=1\right)$ & $P\left(\right.$ Entry $\left._{d}=1\right)$ \\
\hline Number of immigrants & $\begin{array}{c}0.021^{a} \\
(0.001)\end{array}$ & $\begin{array}{c}0.022^{a} \\
(0.001)\end{array}$ \\
\hline Gross domestic product & $\begin{array}{c}0.004^{a} \\
(0.003)\end{array}$ & $\begin{array}{c}0.004^{a} \\
(0.003)\end{array}$ \\
\hline Population & $\begin{array}{c}0.007^{a} \\
(0.000)\end{array}$ & $\begin{array}{c}0.009^{a} \\
(0.000)\end{array}$ \\
\hline Distance & $\begin{array}{c}-0.014^{a} \\
(0.000)\end{array}$ & $\begin{array}{l}-0.014^{a} \\
(0.000)\end{array}$ \\
\hline Common language & $\begin{array}{l}-0.042^{a} \\
(0.000)\end{array}$ & $\begin{array}{l}-0.042^{a} \\
(0.000)\end{array}$ \\
\hline Landlocked & $\begin{array}{l}-0.003^{a} \\
(0.000)\end{array}$ & $\begin{array}{l}-0.003^{a} \\
(0.000)\end{array}$ \\
\hline Exporter productivity & $\begin{array}{l}0.0029^{a} \\
(0.000)\end{array}$ & \\
\hline Exporter-year fixed effects & Yes & \\
\hline Exporter-destination fixed effects & & Yes \\
\hline Destination-year fixed effects & & Yes \\
\hline$R$-squared & 0.09 & 0.14 \\
\hline
\end{tabular}

(Notes) (i) All independent variables, apart from language and landlocked, are in log terms. $p$-values are in brackets.

(ii) Statistical significance levels are denoted by ${ }^{a}\left(1 \%\right.$ or less), ${ }^{b}$ ( $5 \%$ or less), and ${ }^{c}(10 \%$ or less).

We now turn to the effect of migrant networks on the export performance of each firm, conditional on exporting to that market. From Equation (4), we specify the revenueestimating equation as:

$$
\text { ln } \text { Exports }_{e d}=\alpha \text { lnImmigrants }_{d}+\beta X_{d}+\gamma_{e}+u_{d}
$$


where Exports $s_{\text {ed }}$ is the export revenues obtained by exporter $e$ at destination $d$, and the remaining regressors have the meaning defined above. The theory we adopt and the empirical analysis of the previous section suggest that exporters self-select into export markets. An important difficulty in estimating Equation (8) is, therefore, that non-zero export revenues are only observed for the subset of destinations that exporter $d$ enters. Due to sample selection, OLS estimation on non-zero export revenues may deliver biased estimates on the effect of migrant networks on export performance. So, we employ two alternative methods - Tobit procedure and Heckman selection model - to account for potential selection bias in the estimation of Equation (8).

First, we adopt the Tobit procedure. The main advantage of the Tobit estimator is that the correction procedure relies solely on the link between theory and observed trade flow data. Second, for robustness, we also use a Heckman correction approach similar to Helpman et al. (2008). To avoid identification based on functional form, the Heckman selection model requires identifying at least one variable that affects export participation but not export performance. From Section III, we see that this requirement is fulfilled by a variable that influences solely fixed costs of exporting. In line with Helpman et al. (2008), we use measures of entry costs based on World Bank data that may plausibly satisfy this requirement. As a benchmark, we also present the results of OLS estimates of Equation (4) on non-zero export revenues.

Table 5 reports the OLS, Tobit, and Heckman sample selection model estimates. The OLS estimates are solely based on non-zero export flows and are reported in column 1. The specifications in column 1 use an exporter fixed effects estimator to account for exporter heterogeneity. Column 2 reports the Tobit estimates. In this case, the estimation sample includes both zero and positive exporter-level bilateral trade flows and the dependent variable is left-censored by the minimum value of In Exports to account for sample selection. The corresponding effects confirm the theoretical prediction that conditional on selection into export markets, more productive firms obtain larger revenues. Of most interest to our present analysis, the marginal effects of migrant networks on export intensity are positive and statistically significant at the $1 \%$ level but are now larger in magnitude. Therefore, conditional on an exporter serving a market, the presence of emigration stocks appears to be an important determinant of how much it sells there. A potential concern with the Tobit estimation is that the censoring point might be measured with error. To assess if the estimates are sensitive to the proxy for the entry threshold, we also looked at the marginal effects from Tobit estimation, but with the dependent variable left-censored at zero. Reassuringly, the 
estimates remain similar. ${ }^{9}$ In both cases, the estimates point to a positive and statistically significant relationship between export volumes and migrant networks.

For further robustness, column 3 of Table 5 reports the results of a Heckman sample selection model. In line with Helpman et al. (2008), we use World Bank data on destination-specific regulation costs of exporter entry to proxy for fixed costs of exporting. These indicators consist of the cost, number of procedures, and the number of days it takes an entrepreneur to legally start a business. Column 3 reports the corresponding estimates of the Heckman selection model for the export revenue equation.

The estimation can be conducted using full maximum likelihood or the two-step method proposed by Heckman (1979). We report results from the former method only, but have verified that the latter yields very similar estimates. As before, the results point to a positive and statistically significant relationship between export revenue and migrant networks.

${ }^{9}$ Results are available but not included for space purposes. 
Table 5. Robustness checks

\begin{tabular}{|c|c|c|c|}
\hline \multirow{2}{*}{ Dependent variable } & \multicolumn{3}{|c|}{ Exports $_{\text {ed }}$} \\
\hline & OLS & Tobit & Heckman \\
\hline Exporter productivity & & $\begin{array}{c}1.625^{a} \\
(0.000)\end{array}$ & $\begin{array}{c}0.312^{a} \\
(0.000)\end{array}$ \\
\hline Number of immigrants & $\begin{array}{c}0.412^{a} \\
(0.000)\end{array}$ & $\begin{array}{c}0.743^{a} \\
(0.000)\end{array}$ & $\begin{array}{c}0.072^{a} \\
(0.000)\end{array}$ \\
\hline Gross domestic product & $\begin{array}{c}0.112^{a} \\
(0.000)\end{array}$ & $\begin{array}{l}2.751^{a} \\
(0.000)\end{array}$ & $\begin{array}{c}0.138^{a} \\
(0.000)\end{array}$ \\
\hline Population & $\begin{array}{c}0.094^{a} \\
(0.000)\end{array}$ & $\begin{array}{l}1.829^{a} \\
(0.000)\end{array}$ & $\begin{array}{c}0.081^{a} \\
(0.000)\end{array}$ \\
\hline Distance & $\begin{array}{l}-0.674^{a} \\
(0.000)\end{array}$ & $\begin{array}{l}-0.593^{a} \\
(0.000)\end{array}$ & $\begin{array}{c}-0.434^{a} \\
(0.000)\end{array}$ \\
\hline Common language & $\begin{array}{l}-0.414^{c} \\
(0.071)\end{array}$ & $\begin{array}{l}-4.123^{c} \\
(0.062)\end{array}$ & $\begin{array}{c}-0.256^{a} \\
(0.000)\end{array}$ \\
\hline Landlocked & $\begin{array}{l}-0.723^{a} \\
(0.008)\end{array}$ & $\begin{array}{c}-19.457^{c} \\
(0.082)\end{array}$ & $\begin{array}{c}-0.773^{a} \\
(0.000)\end{array}$ \\
\hline Procedures & & & $\begin{array}{l}-0.012^{a} \\
(0.000)\end{array}$ \\
\hline Time & & & $\begin{array}{c}-0.037^{a} \\
(0.000)\end{array}$ \\
\hline Cost & & & $\begin{array}{c}-0.049^{a} \\
(0.000)\end{array}$ \\
\hline Exporter-year fixed effects & Yes & No & No \\
\hline Destinations & 180 & 180 & 163 \\
\hline$R$-squared & 0.21 & 0.17 & \\
\hline Log likelihood & & & $-251,821$ \\
\hline
\end{tabular}

(Notes) (i) All variables, apart from language and landlocked, are in log terms. $p$-values are in brackets.

(ii) Statistical significance levels are denoted by ${ }^{a}$ ( $1 \%$ or less), ${ }^{b}\left(5 \%\right.$ or less), and ${ }^{c}(10 \%$ or less). 


\section{Conclusion}

This study examines the relationship between diaspora and exporters dynamics by exploiting disaggregated exporter-level data from Iran. We find that the size of the emigrant pool from Iran to a destination matters for Iranian exporters: countries with more emigrants from Iran attract more Iranian exporters, products, and exports. One explanation is that the existence of immigrants helps exporters establish networks faster and, thus, reduces market entry costs as well as boosts demand of their products. And, our work overcomes a potential endogeneity problem between immigration and trade given that immigration data are historically determined and not affected by the existence of current trade relationships.

Our work has two policy implications. First, given Iran is now trying to integrate more with the global economy, our results imply that Iranian embassies across the world have a role to play - e.g., by encouraging trade promotion exhibitions and workshopsin bridging the gap between diaspora and Iran to promote greater trade between Iran and the rest of the world. Second, the results in this study highlight the importance of emigration for trade and economic growth for countries with different economic and cultural backgrounds. Despite many attempts to promote economic integration among countries in the Middle East and North Africa (MENA) regions and convergence to the outside world, economic interactions have remained limited. The results of various gravity model calculations suggest that intra-regional trade in MENA is below its potential. Intra-regional trade is a small fraction (5.9\% in exports, $5.1 \%$ in imports) of MENA countries' total trade, where regional trade in Europe amounts to about $60 \%$. Moreover, MENA's exports to the outside world were only one-third of their potential. It would take 20 years for MENA countries to reach their trade potential. Middle East intra-regional and inter-regional trade could bring more economic integration, which in turn, would promote peace, stability, and prosperity in the Middle East and prevent conflicts while boosting regional economic cooperation. Further research can discuss how exporters build distribution networks in the presence or absence of immigrants.

Received 29 April 2014, Revised 31 March 2016, Accepted 8 April 2016 


\section{References}

James E. Anderson and Douglas Marcouiller, "Insecurity and The Pattern Of Trade: An Empirical Investigation," The Review of Economics and Statistics 84(2002): 342-352.

James E. Anderson and Erik van Wincoop, "Trade Costs," Journal of Economic Literature 42(2004): 691-751.

Robert J. Barro and Rachel M. McCleary, "Religion and Economic Growth across Countries," American Sociological Review 68(2003): 760-781.

Subhayu Bandyopadhyay, Cletus C. Coughlin, and Howard J. Wall, "Ethnic networks and U.S. exports," Review of International Economics 16(2008): 199-213.

Daniel Berkowitz, Johannes Moenius, and Katharina Pistor, "Trade, Law, and Product Complexity," The Review of Economics and Statistics 88(2006): 363-373.

Jose V. Blanes and Joan Martin-Montaner, "Migration Flows and Intra-industry Trade Adjustments," Review of World Economics 142(2006): 567-584.

Dale Boisso and Michael Ferrantino, "Economic Distance, Cultural Distance, and Openness in International Trade: Empirical Puzzles," Journal of Economic Integration 12(1997): 456-484.

George J. Borjas, "The Economic Benefits from Immigration," Journal of Economic Perspectives 9(1995): 3-22.

Thomas Chaney, "Distorted Gravity: The Intensive and Extensive Margins of International Trade," American Economic Review 98(2008): 1707-1721.

Catherine Co, Patricia Euzent, and Thomas Martin, "The Export Effect of Immigration into the USA," Applied Economics 36(2004): 573-583.

Pierre P. Combes, Miren Lafourcade, and Thierry Mayer, "The Trade-Creating Effects of Business and Social Networks: Evidence from France," Journal of International Economics 66(2005): 1-29.

Cletus Coughlin and Howard Wall, "Ethnic Networks and Trade: Intensive versus Extensive Margins," Economics Letters, 113(2011): 73-75.

Lisa M. DeBruine, "Facial Resemblance Enhances Trust," The Proceeding of the Royal 
Society 269(2002): 1307-1312.

Jonathan Eaton, Samuel Kortum, and Francis Kramarz, "An Anatomy of International Trade: Evidence from French Firms,” Econometrica 79 (2011): 1453-1498.

Sourafel Girma and Zhihao Yu, "The Link between Immigration and Trade: Evidence from the United Kingdom," Review of World Economics 138(2002): 115-130.

Paola Giuliano, "Living Arrangements in Western Europe: Does Cultural Origin Matter?," Journal of the European Economic Association 5(2007): 927-952.

David Gould, "Immigrant Links to the Home Country: Empirical Implications for U.S. Bilateral Trade Flows," Review of Economics and Statistics 76 (1994): 302-316.

Jamal Ibrahim Haidar, "Sanctions and Export Deflection: Evidence from Iran," Economic Policy, forthcoming.

Keith Head and John Ries, "Immigration and Trade Creation: Econometric Evidence from Canada," Canadian Journal of Economics 31(1998): 47-62.

Elhanan Helpman, Marc Melitz, and Yona Rubinstein, "Estimating Trade Flows: Trading Partners and Trading Volumes," Quarterly Journal of Economics 123(2008): 441-487.

Rocco Huang, "Distance and Trade: Disentangling Unfamiliarity Effects and Transport Cost Effects," European Economic Review 51(2007): 161-181.

David Hummels and Georg Schaur, "Time as a Trade Barrier," American Economic Review 103(2013): 2935-59.

David Law, Murat Genc, and John Bryant, "Trade, Diaspora and Migration to New Zealand," The World Economy 36(2013): 582-606.

Marina Murat and Barbara Pistoresi, "Migrant Networks: Empirical Implications for the Italian Bilateral Trade," International Economic Journal 23(2009): 371-390.

Nathan Nunn, "Relationship-Specificity, Incomplete Contracts, and the Pattern of Trade," Quarterly Journal of Economics 122(2007): 569-600.

Andromachi Piperakis, Chris Milner, and Peter Wright, "Immigration, Trade Costs, and Trade: Gravity Evidence for Greece," Journal of Economic Integration 18(2003): 750762.

Daniel Trefler, "The Case of the Missing Trade and Other Mysteries," American Economic 
Review 85(1995): 1029-46.

James Rauch and Vitor Trindade, "Ethnic Chinese Networks in International Trade," The Review of Economics and Statistics 84(2002): 116-130.

Roger White and Bedassa Tadesse, "Cultural Distance and the US Immigrant-Trade Link," World Economy 31(2008): 1078-1096. 